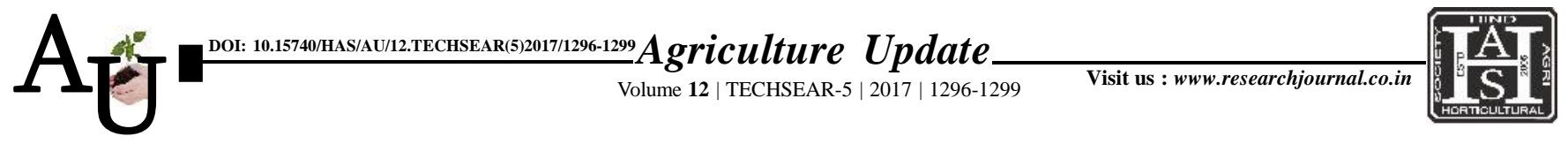

\title{
Research Article: Optimization of irrigation water for drip irrigated Rabi sorghum by using aquacrop model
}

\author{
C. SATISH, K. AVIL KUMAR, V. PRAVEEN RAO AND M. ROJA
}

Article Chronicle:

Received :

15.07.2017;

Accepted :

30.07.2017

KEY WoRDS:

Drip irrigation, Optimization, Rabi sorghum, AquaCrop model

SUMMARY : The field experiment was conducted during Rabi 2014-2015 with CSH-16 sorghum hybrid at Water Technology Center, College farm, College of Agriculture, Rajendranagar, Professor Jayashankar Telangana State Agricultural University, Hyderabad to study the effect of different drip irrigation levels on optimization of drip irrigated Rabi sorghum i.e. drip irrigation at estimated 0.6 ETc throughout the life $\left(\mathrm{I}_{1}\right), 0.8 \mathrm{ETc}$ throughout the life $\left(\mathrm{I}_{2}\right), 1.0$ ETc throughout the life $\left(\mathrm{I}_{3}\right), 1.2 \mathrm{ETc}$ throughout the life $\left(\mathrm{I}_{4}\right)$, 0.6 ETc upto flowering $0.8 \mathrm{ETc}$ later on $\left(\mathrm{I}_{5}\right), 0.6 \mathrm{ETc}$ upto flowering $1.0 \mathrm{ETc}$ later on $\left(\mathrm{I}_{6}\right), 0.6 \mathrm{ETc}$ upto flowering 1.2 ETc later on $\left(\mathrm{I}_{7}\right), 0.8 \mathrm{ETc}$ upto flowering 1.0 ETc later on $\left(\mathrm{I}_{8}\right), 0.8 \mathrm{ETc}$ upto flowering 1.2 ETc later on $\left(\mathrm{I}_{9}\right)$ and in addition to surface furrow irrigation at $0.8 \mathrm{IW} / \mathrm{CPE}$ ratio $\left(\mathrm{I}_{10}\right)$. Results indicated that Observed grain yield values varied at estimated 0.6 ETc with drip irrigation $4209 \mathrm{~kg} \mathrm{ha}^{-1}$ to $8464 \mathrm{~kg} \mathrm{ha}^{-}$ ${ }^{1}$ at 1.2 ETc among different irrigation levels to Rabi sorghum during 2014-15, while simulated grain by AquaCrop model ranged from $4030 \mathrm{~kg} \mathrm{ha}^{-1}$ to $8075 \mathrm{~kg} \mathrm{ha}^{-1}$, respectively under the same irrigation treatments. The observed and simulated yields were almost equal; correlation coefficient is 0.98 , so Aqua Crop model can be used under varying moisture levels.

How to cite this article : Satish, C., Kumar, K. Avil, Rao, V. Praveen and Roja, M. (2017). Optimization of irrigation water for drip irrigated Rabi sorghum by using aquacrop model. Agric. Update, 12(TECHSEAR-5) : 1296-1299; DOI: 10.15740/HAS/AU/12.TECHSEAR(5)2017/1296-1299.

Author for correspondence :

\section{SATISH}

Water Technology

Centre, College of

Agriculture, Professor

Jayashankar Telangana

State Agricultural

University,

Rajendranagar,

HYDERABAD

(TELANGANA) INDIA

See end of the article for

authors' affiliations 